\title{
Testotoxicosis: Report of Two Cases, One with a Novel Mutation in LHCGR Gene
}

\author{
Bahar Özcabı1, Feride Tahmiscioğlu Bucak1, Serdar Ceylaner2, Rahşan Özcan3, Cenk Büyükünal3, \\ Oya Ercan1, Beyhan Tüysüz4', Olcay Evliyaoğlu1 \\ 1/stanbul University Cerrahpaşa Faculty of Medicine, Department of Pediatric Endocrinology, Istanbul, Turkey \\ 2Intergen Genetics Centre, Ankara, Turkey \\ 3/stanbul University Cerrahpaşa Faculty of Medicine, Department of Pediatric Surgery, Istanbul, Turkey \\ ${ }^{4}$ Istanbul University Cerrahpaşa Faculty of Medicine, Department of Pediatric Genetic, Istanbul, Turkey
}

\begin{abstract}
Testotoxicosis is a rare disorder which presents as isosexual peripheral precocious puberty in males. Despite the pattern of autosomal dominant inheritance, sporadic cases also may occur. Due to activating mutation in luteinizing hormone (LH))/choriogonadotropin receptor (LHCGR) gene, early virilization and advancement in bone age are common with increased serum testosterone levels above adult ranges, despite low $\mathrm{LH}$ and follicularstimulating hormone (FSH) levels. There are different treatment regimens, such as combination of bicalutamide (antiandrogen agent) and a third-generation aromatase inhibitor, that are reported to be well-tolerated and successful in slowing bone age advancement and preventing progression of virilization. We report here two patients who presented with peripheral precocious puberty and an activating mutation in the LHCGR gene: one with a family history and previously determined mutation and the other without family history and with a novel mutation (c.830G $>$ T). Combination of bicalutamide+anastrozole was ineffective in slowing pubertal progression and bone age. Short-term results were better with ketoconazole.
\end{abstract}

Key words: Testotoxicosis, microlithiasis, anastrozole, bicalutamide, cyproterone acetate, ketoconazole

Conflict of interest: None declared

Received: 17.04 .2015

\section{Introduction}

First described by Schedewei et al (1), familial malelimited precocious puberty is a rare, autosomal dominant form of gonadotropin-independent precocious puberty in males. Sporadic cases were also reported $(2,3)$. In this condition, due to activating mutations in luteinizing hormone (LH)/choriogonadotropin receptor gene (LHCGR), testicular steroidogenesis and spermatogenesis are stimulated $(1,2,4)$.

This disorder was also called "testotoxicosis" by Rosenthal et al (2) The age of onset is usually 2-4 years. Unilateral or bilateral testicular growth is observed. Nodular Leydig cell hyperplasia can be observed and seminiferous tubular development is usually sufficient to allow spermatogenesis $(2,3,5,6)$. Due to activating mutation in the LHCGR gene, an extremely muscular body build, accelerated growth and advanced bone age are commonly observed. Testosterone levels are in or above the adult male range with low $\mathrm{LH}$ and follicular-stimulating hormone (FSH) levels. Central precocious puberty typically follows over time. After the maturation of hypothalamo-pituitary-testicular axis, normal adult function appears to range from normal paternity to reduced testicular volume or oligospermia (7).

Although the reported mutations in familial and sporadic cases had a genetic heterogeneity, they were usually sited in exon $11(3,4,8,9,10,11)$. However, further studies revealed that there were a considerable number of cases, especially sporadic forms, whose mutations were sited in exons other than $11(10,12)$. In order to reduce the synthesis and action of androgens, several agents such as medroxiprogesterone, ketoconazole, cyproterone have been used for treatment. Aromatase inhibitors are also included in treatment regimens for slowing of bone age advancement. In recent studies, different 
combinations of new generation aromatase inhibitors and antiandrogen agents such as bicalutamide have been reported and recommended for the treatment of difficult cases $(13,14,15,16$, $17,18,19,20,21,22,23)$.

We report here two patients who presented with an activating mutation in the LHCGR gene: one familial with a previously reported mutation and one sporadic with a novel mutation (c.830G $>\mathrm{T}$ ), in whom combination of bicalutamide+anastrozole treatment was ineffective.

\section{Case Reports}

\section{Patient 1}

A 1.4-year-old boy was admitted with complaints of pubic hair development, penile enlargement, linear growth acceleration, acne and increased aggressive behavior. His mother had become aware of enlargement of the genitals by 6 months of age. He had healthy parents non-consanguineously married and there was no family history of precocious puberty. At physical examination, his height was $96 \mathrm{~cm}(+5.38$ standart deviation score (SDS)) and weight was $17 \mathrm{~kg}(+2.0$ SDS). $\mathrm{He}$ had an extremely muscular body build, a deepened voice and acne. Penile stretch length was $13 \mathrm{~cm}$ (>2 SDS); the left testicular volume was $3 \mathrm{~mL}$ and the right was $4 \mathrm{~mL}$. Pubic hair was appropriate for Tanner stage 3 (Figure 1a). He did not have any café au lait spots.

Bone age was 4 years by the Greulich-Pyle method. Midparental height (MPH) SDS was 0.83. Clinical, auxological and endocrinological findings at admission are summarized in Table 1. The patient's serum testosterone level was very high and gonadotropin-releasing hormone $(\mathrm{GnRH})$ stimulation test revealed a prepubertal response. Thyroid function tests (free triiodothyronine $\left(\mathrm{T}_{3}\right): 4.4 \mathrm{pg} / \mathrm{dL}$; free thyroxine $\left(\mathrm{T}_{4}\right): 1.1 \mathrm{ng} / \mathrm{dL}$; thyroid-stimulating hormone (TSH): $2.5 \mathrm{mIU} / \mathrm{L})$ and adrenal cortex hormone levels (dehydroepiandrosterone sulfate (DHEA$\mathrm{SO}_{4}$ ): $37.2 \mu \mathrm{g} / \mathrm{dL}$; 17- $\alpha$-hydroxyprogesterone (17-OHP): $0.9 \mathrm{ng} /$ $\mathrm{dL}$; androstenedione: $0.5 \mathrm{ng} / \mathrm{mL}$; cortisol: $10.7 \mu \mathrm{g} / \mathrm{dL}$ ) were within normal ranges. Peripheral precocious puberty findings with a testicular volume of $4 \mathrm{~mL}$ suggested a tumor secreting

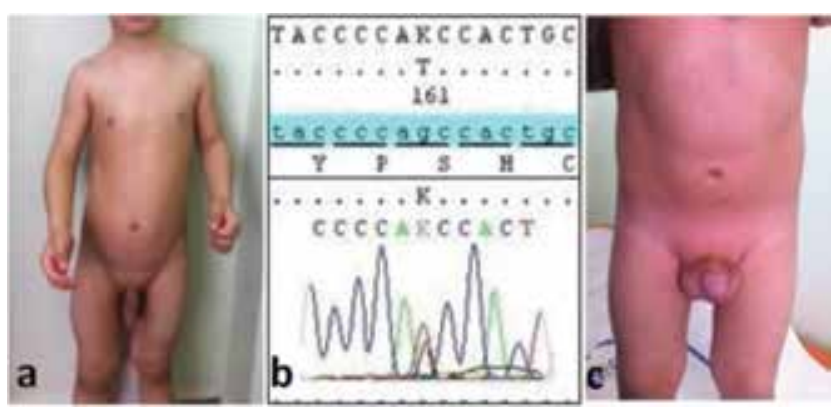

Figure 1. Note the enlarged external genitalia, extremely muscular body build (a) and novel mutation c.830G >T (p.S277l) in the LHCGR gene (b) of patient 1 and also the enlarged external genitalia of patient 2 (c) beta-human chorionic gonadotropin (hCG) or a testicular tumor secreting testosterone; an activating mutation in the $\mathrm{LH}$ receptor and McCune Albright syndrome were also considered. Abdominal magnetic resonance imaging (MRI) revealed normal findings. A low serum beta-hCG $(<1.20 \mathrm{mIU} / \mathrm{L})$ level excluded presence of a beta-hCG-secreting tumor. He did not have any abnormality in bone scintigraphy screening. A testicular ultrasonography showed a solid mass of a size of $2 \times 2 \mathrm{~mm}$ in the right testicle. A surgical intervention was performed. During the operation, the testis was mobilized by inguinal incision and a $2 \times 2$ mass was detected. In cold ischemia conditions, the mass was excised by testis-saving procedure and sent for histopathological evaluation. Pathological examination revealed nodular Leydig cell hyperplasia. After surgery, serum total testosterone level did not decline. Anti-androgen treatment with bicalutamide (50 mg/day) and aromatase inhibition with anastrozole (1 mg/day) were initiated. A normal testosterone level could not be obtained and another surgery was planned. The same inguinal incision was performed and vascular pedicle was secured in cold ischemia conditions. The mass was not localized by visual examination. Intraoperative ultrasonography demonstrated a $3 \times 3 \mathrm{~mm}$ mass and with the guidance of the probe, the mass was found and excised by another testissaving procedure. Histopathological examination revealed the diagnosis of nodular Leydig cell hyperlasia again. Since the patient met the criteria for the diagnosis of testotoxicosis, a genetic analysis for LHCGR gene was performed. Sequence analysis of all coding regions and exon-intron boundaries were done by in house designed primers using Sanger sequencing technique and a novel mutation c.830G > T (p.S277l) (heterozygous) was described (Figure 1b). In silico evaluation tools including Mutation taster, SIFT and Polyphen 2 predict this variant as a disease-causing mutation. Parental analysis was normal, then this variation was most probably a de novo pathogenic variant. Screening of 200 healthy people for this variant was done and no one had this mutation.

Cyproterone acetate was added to the treatment regimen because the suppression of pubertal progression and serum testosterone levels was not sufficient, but it was withdrawn in one month because of increases in liver enzymes which could not be associated with another cause; liver enzymes became normal after the cessation of the drug.

In the $20^{\text {th }}$ month of treatment, $\mathrm{GnRH}$ stimulation revealed a pubertal response and a $\mathrm{GnRH}$ analogue was added to treatment. In his follow-up at age 3.8 years, despite bicalutamide (100 mg/day), anastrozole (2 mg/day) and $\mathrm{GnRH}$ analogue treatments, sufficient suppression of puberty and decline in serum testosterone levels were not achieved (Table 2). Antiandrogen treatment with bicalutamide (androgen receptor antagonist) was changed to ketoconazole (androgen synthesis inhibitor) in a dose of $10 \mathrm{mg} / \mathrm{kg} /$ day. A treatment regimen of ketoconazole, anastrozole and a $\mathrm{GnRH}$ analogue led to a decline in serum testosterone level from $900 \mathrm{ng} / \mathrm{dL}$ to $490 \mathrm{ng} / \mathrm{dL}$ on 
Table 1. Clinical, auxological and endocrinological data of the patients at admission

\begin{tabular}{|l|l|l|}
\hline & Patient 1 & Patient 2 \\
\hline Age at onset of symptoms & 6 months & 17 months \\
\hline LH receptor mutation & c.830G $>$ T (p.S277l) & c.1118 C>T (p.A373V) \\
\hline Family members with mutation & $(-)$ & $(+)$ (mother) \\
\hline Chronological age & 1.4 years & 1.5 years \\
\hline Bone age & 4 years & 3.5 years \\
\hline Height SDS for chronological age1 & 5.4 & 3.1 \\
\hline Height SDS for bone age & -1.9 & -1.6 \\
\hline Pubertal stage & 2 & 2 \\
\hline Penis length SDS & $>2$ & $>2$ \\
\hline Unilateral testicular volume (mL)1 & 4 & 4 \\
\hline Mid-parental height SDS & 4 & 1.3 \\
\hline Serum testosterone (ng/dL) & 0.8 & 479.2 \\
\hline Plasma LH (basal/peak after GnRH, IU/L) & 1010 & $0.1 / 2.7$ \\
\hline Plasma FSH (basal/peak after GnRH, IU/L) & $<0.1 / 0.4$ & $0.114 / 4.0$ \\
\hline $\begin{array}{l}\text { 1The largest of the two testes } \\
\text { SDS: standart deviation score, LH: luteinizing hormone, FSH: follicular-stimulating hormone, GnRH: gonadotropin-releasing hormone }\end{array}$ \\
\hline
\end{tabular}

Table 2. Data at cessation of bicalutamide+anastrozole treatment

\begin{tabular}{|l|l|l|}
\hline & Patient 1 & Patient 2 \\
\hline Duration of treatment (months) & 32 & 18 \\
\hline Chronological age (years) & 4 & 3 \\
\hline Bone age (years) & 12.5 & 5.5 \\
\hline${ }^{1} \Delta$ chronological age (months)/ ${ }^{\Delta}$ bone age (months) & $32 / 102$ & $18 / 24$ \\
\hline Growth velocity (cm/yr)/Growth velocity SDS & $10.8 \mathrm{~cm} / 3.3$ & $7.5 \mathrm{~cm} /-0.2$ \\
\hline Height SDS for chronological age & 3.6 & 2.57 \\
\hline Height SDS for bone age & -3.4 & -1.4 \\
\hline Serum testosterone (ng/dL) & 904 & 497.8 \\
\hline GnRH treatment & Yes & No \\
\hline $\begin{array}{l}{ }^{1} \text { Change in chronological age between beginning and cessation of biculutamide treatment } \\
{ }^{2} \text { Change in bone age between beginning and cessation of biculutamide treatment } \\
\text { SDS: standart deviation score, GnRH: gonadotropin-releasing hormone }\end{array}$ & & \\
\hline
\end{tabular}

the $3^{\text {rd }}$ day of the treatment. At the $3^{\text {rd }}$ month of ketoconazole $(15 \mathrm{mg} / \mathrm{kg} / \mathrm{d}$ ) treatment, serum testosterone level decreased to $125 \mathrm{ng} / \mathrm{dL}$ without any sign of side effects; whether this benefit will be sustained or not needs to be evaluated in the long term.

\section{Patient 2}

Patient 2 was admitted at the age of 1.5 years with complaints of pubic hair development, penile enlargement and linear growth acceleration. His mother had become aware of the symptoms 1 month before admission. He had healthy parents with a non-consanguineous marriage, but in the family history, there were other cases of precocious puberty.
At physical examination, the patient's height was $94.2 \mathrm{~cm}$ (+3.1 SDS) and his weight was $16.5 \mathrm{~kg}$ (+2.9 SDS). Stretched penile length was $6 \mathrm{~cm}$ (>2 SDS); left testicular volume was $3 \mathrm{~mL}$ and right testicular volume was $4 \mathrm{~mL}$. Pubic hair was Tanner stage 2 (Figure 1c). He did not have any café au lait spots.

His bone age was 3.5 years by the Greulich-Pyle method. MPH SDS was 1.3. Clinical, auxological and endocrinological findings at admission are summarized in Table 1. Similar to the first patient, serum testosterone level was very high and $\mathrm{GnRH}$ stimulation test revealed a prepubertal response. Thyroid function tests were within normal ranges (free $T_{3}: 5.2$ 
Özcabı B et al.

Bicalutamide Treatment in Testotoxicosis

$\mathrm{pg} / \mathrm{dL}$, free $\left.\mathrm{T}_{4}: 1.1 \mathrm{ng} / \mathrm{dL}, \mathrm{TSH}: 3.2 \mathrm{mIU} / \mathrm{L}\right)$. Baseline 17-OHP level was $6.1 \mathrm{ng} / \mathrm{dL}$ and peak level was $11.6 \mathrm{ng} / \mathrm{mL}$ by an adrenocorticotropic hormone stimulation test. CYP21 gene analysis revealed no mutation. He had normal abdominal MRI. Low serum beta-hCG ( $<1.2 \mathrm{mlU} / \mathrm{L})$ level excluded an hCG-secreting tumor. There was no tumoral mass in testicular ultrasound, but it revealed bilateral hydrocele and microlithiasis. Bone scintigraphy was normal. A combination of bicalutamide (50 mg/day)+anastrozole (1 mg/day) treatment was started. At the genetic analysis for testotoxicosis, sequence analysis of all coding regions and exon-intron boundaries of LHCGR gene was done by in house designed primers using Illumina Miseq Next Generation sequencing technique and a known mutation c.1118C > T (p.A373V) (heterozygous) was determined. Analyses in the parents showed that the mother also had this mutation.

Despite the treatment, as also was the case in the former patient, sufficient suppression of puberty characteristics and decline in serum testosterone levels were not achieved at 24 months of treatment (Table 2). Bicalutamide treatment was switched to ketoconazole $(10 \mathrm{mg} / \mathrm{kg} /$ day) and anastrozole (2 mg/day) treatment was continued. Serum testosterone level declined to $10 \mathrm{ng} / \mathrm{dL}$ from $490 \mathrm{ng} / \mathrm{dL}$ on the third day of treatment. At the end of the first month of this combination treatment, as total testosterone level increased to $23 \mathrm{ng} / \mathrm{dL}$, the ketoconazole dose was raised to $15 \mathrm{mg} / \mathrm{kg} /$ day. Gonadotropin levels were still in prepubertal ranges and total testosterone levels did never exceeded $23 \mathrm{ng} / \mathrm{dL}$ after the dose increment. At the 6th month of follow-up with ketoconazole and anastrozole, serum testosterone level was $15 \mathrm{ng} / \mathrm{dL}$ without any side effect and bone age was still appropriate for age 5.5 years.

\section{Discussion}

Testotoxicosis becomes usually symptomatic by 2-4 years of age; however, in some cases, the clinical signs and laboratory findings of puberty appear earlier (2,3). Teles et al (9) reported a healthy 10-month-old boy investigated because of an older brother with familial testotoxicosis. The same heterozygous mutation Thr577lle was determined and the bone age was found to be advanced. In this patient, despite lack of virilization signs, cyproterone acetate was started at the age of 1.3 years in order to decrease testosterone levels and growth velocity. In our first patient, pubic hair development and penile enlargement had started at the age of six months and, to our knowledge, he is the youngest patient with virilization symptoms. We can speculate that this early and severe clinical aspect was related to the novel c.830G>T (p.S277l) mutation in the LHCGR gene.

In patients with testotoxicosis, in addition to clinical and laboratory investigations, genetic analyses are beneficial for diagnosis and follow-up. Several mutations were reported in Caucasian, Afro-American and Brazilian populations. There has been genetic heterogeneity, but mutations were usually sited in exon $11(3,4,8,9,10,11)$. However, further studies revealed that there were a considerable number of cases, especially sporadic forms, in which mutations were commonly sited in exons other than $11(10,12)$. In patient 1, a novel mutation c.830G > T (p.S277l) (heterozygous) was determined in exon 9 of LHCGR gene and he is a sporadic case. According to his family history, patient 2 probably had familial testotoxicosis, but unfortunately, the other family members with probable testotoxicosis did not give permission for investigation. Our second patient and his mother had the mutation c.1118C>T (p.A373V) (heterozygous) previously reported by Gromoll et al (11) in 11 exon of LHCGR gene. Some studies have attempted to establish an association between phenotype and genotype $(3,10,11)$. Signs of precocious puberty appeared at age 17 months in our patient 2, while the patient who had the same mutation and was reported by Gromoll et al (11) had signs at the age of 5 years. Although presentation ages were different, ketoconazole treatment was effective in both cases in the short term.

Independently from treatment, testotoxicosis can cause testicular changes. In biopsy specimens from patients with testotoxicosis, Gondos et al (5) observed that the morphologic changes indicated premature differentiation of all of the major testicular cell types. Leydig cells demonstrated nuclear and cytoplasmic features characteristic of fully differentiated steroidogenic cells; germ cells at all stages of spermatogenesis were present, but their maturation was disorganized and spermatids had structural abnormalities. In 1998, Martin et al (24) reported testicular seminoma in an adult patient. He was diagnosed at the age of 27 months and had the A578G mutation in LHCGR gene. However, seminoma is not the only cause of solid mass in testes of affected patients. Leschek et al (6) reported nodular Leydig cell hyperplasia in a patient with testotoxicosis who had A564G mutation. Thus, our first patient is the second reported case with nodular cell hyperplasia which might be due to overstimulation of Leydig cells. Testicular microlithiasis determined in patient 2 is an uncommon condition characterized by calcium deposits in the lumina of seminiferous tubules. These intratesticular calcifications appear as bright, 2- to 3-mm echogenic foci on testicular ultrasound. It might be a benign condition with a potential for malignancy. It is reported that this ultrasonographic sign can occur in many conditions such as germ cell tumors, epididymitis, cryptorchidism, retractile testis and hypotrophic testis $(25,26,27)$. While observed in some cases $(25,26)$, hydrocele is not a common cause of testicular microlithiasis (27). Microlithiasis has also not been reported in patients with LH-activating mutations; Gougoudi et al (28) reported that testicular microlithiasis co-existed with Leydig cell hyperplasia in Wistar rats. Thus, whether Leydig cell hyperstimulation in our patient is the cause of microlithiasis or not is not known.

In testotoxicosis, there is no consensus for treatment modality and, as shown in Table 3, different regimens have been 
Özcabı B et al.

Bicalutamide Treatment in Testotoxicosis

\begin{tabular}{|c|c|c|c|c|c|}
\hline $\mathbf{T}$ & Patient & $\begin{array}{l}\text { Age of } \\
\text { onset (yrs) }\end{array}$ & $\begin{array}{l}\text { Mutation } \\
\text { (Heterozygous) }\end{array}$ & Treatment & Clinical benefit and loss \\
\hline $\begin{array}{l}\text { Rosenthal et } \\
\text { al (13) }\end{array}$ & $\begin{array}{l}1 \\
2 \\
3 \\
4\end{array}$ & $\begin{array}{l}3.8 \\
3.4 \\
5.2 \\
3.2\end{array}$ & $\begin{array}{l}\text { Unknown } \\
\text { Unknown } \\
\text { Unknown } \\
\text { Unknown }\end{array}$ & Medroxiprogesterone & Decrement of $\mathrm{T}$ to early puberty levels \\
\hline $\begin{array}{l}\text { Holland et al } \\
\text { (14) }\end{array}$ & $\begin{array}{l}1 \\
2 \\
3\end{array}$ & $\begin{array}{l}\text { NM } \\
\text { NM } \\
\text { NM }\end{array}$ & $\begin{array}{l}\text { Unknown } \\
\text { Unknown } \\
\text { Unknown }\end{array}$ & Ketoconazole + Buserelin & $\begin{array}{l}\text { Decrement of } \mathrm{T} \text { in all the patients } \\
\text { Slight decrease in bone age advancement and growth } \\
\text { velocity in patient } 1\end{array}$ \\
\hline $\begin{array}{l}\text { Bertelloni et } \\
\text { al (7) }\end{array}$ & $\begin{array}{l}1 \\
2 \\
3 \\
4\end{array}$ & $\begin{array}{l}4.2 \\
5 \\
5 \\
3 \\
3\end{array}$ & $\begin{array}{l}\text { M398T } \\
\text { Brother of patient } 1 \\
\text { Unknown } \\
\text { Unknown } \\
\text { M398T }\end{array}$ & $\begin{array}{l}\text { Cyproterone acetate } \\
\text { No treatment } \\
\text { Cyproterone acetate } \\
\text { Ketoconazole } \\
\text { Ketoconazole }\end{array}$ & $\begin{array}{l}\text { Disease unaffected, FH appropriate for MPH } \\
\text { FH appropriate for MPH, decrease in testicular volumes } \\
\text { FH below MPH } \\
\text { Buserelin was added at the } 6^{\text {th }} \text { month of ketoconazole } \\
\text { Reduced height for MPH, oligospermia } \\
\text { Successful puberty inhibition }\end{array}$ \\
\hline $\begin{array}{l}\text { Gromoll et al } \\
\text { (11) }\end{array}$ & 1 & 5 & A373V & Ketoconazole & $\begin{array}{l}\text { Decrement of } \mathrm{T} \\
\text { Triptorelin was added at the } 1^{\text {st }} \text { year of ketoconazole }\end{array}$ \\
\hline $\begin{array}{l}\text { Teles } \\
\text { et al (9) }\end{array}$ & 1 & 1.3 & T577| & Cyproterone acetate & $\begin{array}{l}\text { Decrease in erection frequency } \\
\text { No sign of virilization } \\
\text { Reduction of GW }\end{array}$ \\
\hline $\begin{array}{l}\text { Soriano- } \\
\text { Guillén } \\
\text { et al (15) }\end{array}$ & $\begin{array}{l}1 \\
2 \\
3 \\
4 \\
5\end{array}$ & $\begin{array}{l}2.3 \\
5.6 \\
6 \\
3.1 \\
4\end{array}$ & $\begin{array}{l}\text { M398T } \\
\text { M398T } \\
\text { M398T } \\
\text { I542L } \\
\text { I542L }\end{array}$ & $\begin{array}{l}\text { Ketoconazole } \\
\text { Ketoconazole } \\
\text { Ketoconazole } \\
\text { Ketoconazole } \\
\text { Ketoconazole }\end{array}$ & $\begin{array}{l}\text { Decrement of T } \\
\text { FH similar to TH, significantly higher than PAH }\end{array}$ \\
\hline $\begin{array}{l}\text { Almeida } \\
\text { et al (17) }\end{array}$ & $\begin{array}{l}1 \\
2 \\
3 \\
4 \\
5 \\
6 \\
7 \\
8 \\
9 \\
10\end{array}$ & $\begin{array}{l}\text { NM } \\
\text { NM } \\
\text { NM } \\
\text { NM } \\
\text { NM } \\
\text { NM } \\
\text { NM } \\
\text { NM } \\
\text { NM } \\
\text { NM }\end{array}$ & $\begin{array}{l}\text { A568V } \\
\text { T577I } \\
\text { T577I } \\
\text { L457R } \\
\text { A568V } \\
\text { M571I } \\
\text { L368P } \\
\text { L368P } \\
\text { M571I } \\
\text { A568V }\end{array}$ & $\begin{array}{l}\text { Cyproterone + MP } \\
\text { Cyproterone } \\
\text { Cyproterone } \\
\text { Cyproterone } \\
\text { Cyproterone } \\
\text { Ketoconazole } \\
\text { Ketoconazole } \\
\text { Ketoconazole } \\
\text { Ketoconazole } \\
\text { Ketoconazole }\end{array}$ & $\begin{array}{l}\text { Decrease in GW } \\
\text { Decrease in bone age/chronological age ratio } \\
\text { Decrement of T (significantly lower with ketoconazole than } \\
\text { cyproterone) } \\
\text { Limited efficacy in attaining normal adult height }\end{array}$ \\
\hline $\begin{array}{l}\text { Eysette- } \\
\text { Guerreau } \\
\text { et al (19) }\end{array}$ & 1 & 2.5 & $\begin{array}{l}\text { T5771 } \\
\text { T577I }\end{array}$ & $\begin{array}{l}\text { Ketoconazole/ } \\
\text { Cyproterone+anastrozole } \\
\text { Cyproterone+anastrozole }\end{array}$ & $\begin{array}{l}\text { High level of T, further bone age progression with } \\
\text { ketoconazole. Decrease in GW, FH higher than PAH with } \\
\text { cyproterone+anastrozole (patient 1) } \\
\text { Decrement of GW, stable bone age advancement (patient 2) }\end{array}$ \\
\hline $\begin{array}{l}\text { Mitre } \\
\text { et al (20) }\end{array}$ & 1 & 4 & D312S & Bicalutamide+anastrozole & $\begin{array}{l}\text { Decreased advancement of bone age, secondary sexual } \\
\text { characteristics and aggressiveness (10 months) }\end{array}$ \\
\hline Lenz et al (21) & 2 & 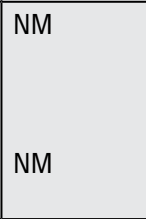 & D578G & $\begin{array}{l}\text { Spironolactone+testolactone } \\
\text { Bicalutamide+anastrozole }\end{array}$ & $\begin{array}{l}\text { Insufficient efficacy in preventing puberty advancement/ } \\
\text { stabilization of bone age with bicalutamid+anastrozole (in } \\
\text { follow-up combinated with leuprolide) (patient 1) } \\
\text { Increase in PAH (in follow-up combinated with leuprolide) } \\
\text { (patient 2) }\end{array}$ \\
\hline $\begin{array}{l}\text { Reiter } \\
\text { et al (22) }\end{array}$ & $n=12$ & NM & NM & Bicalutamide+anastrozole & Slowing GW (1st year of treatment) \\
\hline $\begin{array}{l}\text { Presented } \\
\text { cases }\end{array}$ & $\begin{array}{l}1 \\
2\end{array}$ & $\begin{array}{l}6 \text { months } \\
17 \text { months }\end{array}$ & $\begin{array}{l}\text { S277I } \\
\text { A373V }\end{array}$ & Bicalutamide+anastrozole & $\begin{array}{l}\text { Insufficient effect on reducing T } \\
\text { Increase in bone-age } \\
\text { Decrement of height SDS according to bone age } \\
\text { Central precocious puberty in patient } 1\end{array}$ \\
\hline
\end{tabular}


proposed. Rosenthal et al (13) used oral medroxyprogesterone in two boys and observed distinct decrease in serum total testosterone level and height velocity. One agent which has been widely used is ketoconazole which inhibits adrenal and testicular androgen biosynthesis. Holland et al (14) reported that ketoconazole ( $3 \times 200 \mathrm{mg} / \mathrm{dose}$ ) led to a reduced testosterone levels in three affected patients, but after 1-3 months of treatment, a marked pubertal response to $\mathrm{GnRH}$ stimulation test was found to occur. This phenomenon could question the use of ketoconazole alone (14). Bertelloni et al (7) treated two patients with cyproterone acetate and 2 patients with ketoconazole. Cyproterone acetate was ineffective in clinical progression. Although ketoconazole reduced testosterone secretion and improved the final height in one patient, the second patient had a short adult height of -2 SDS which was below his target height. Conversely, Soriano-Guillén et al (15) observed that final heights of five patients treated with ketoconazole $(16.2 \mathrm{mg} / \mathrm{kg} /$ day) were in concordance with their target heights and were significantly higher than their pretreatment predicted heights. Total testosterone levels with treatment were less than $0.5 \mathrm{ng} / \mathrm{mL}$ and none of the patients had early activation of the pituitary-gonadal axis. Ketoconazole was well-tolerated; only one patient had a transient and modest increase in serum transaminases (15). The main side effect of ketoconazole is hepatic injury that may lead to cirrhosis $(29,30)$. Other side effects such as interstitial pneumonitis have been also reported (16). Cyproterone acetate which antagonizes androgen action at the receptor level is another agent administered in testotoxicosis $(7,17,18)$. Almeida et al (17) reported a multicentric, retrospective, long-term treatment study in which 10 patients were evaluated. Cyproterone acetate was administered to five patients and ketoconazole to five others. Age of onset of disease and duration of treatment were similar. The authors concluded that long-term treatment with cyproterone acetate or ketoconazole resulted in similar outcomes without serious side effect. However, both agents had limited effectiveness on height.

Further studies revealed that new combinations of aromatase inhibitors+anti-androgenagentssuchasanastrozole+cyproterone acetate (19) and anastrozole+bicalutamide $(20,21,22,23)$ were effective in reducing virilization and in decreasing testosterone synthesis without important complications. Lenz et al (21) reported two boys treated with anastrozole+bicalutamide. This combination was well-tolerated, effective in preventing progression of virilization and in slowing bone-age advancement with no decrease in linear growth (21). The weakness of all these studies was the small number of patients or short-term outcomes.

Testotoxicosis may be difficult to treat in some cases. Although bicalutamide treatment has been reported as welltolerated and effective, in the presented 2 patients, it was not successful in reducing serum testosterone levels, bone age advancement and pubertal progression. Short-term laboratory and clinical results of ketoconazole treatment seemed to be more efficacious in these two patients. Long-term studies with large numbers of patients are necessary for evaluation of these agents regarding prognosis, treatment efficacy and long-term effects on adult height, fertility and metabolic parameters.

\section{References}

1. Schedewie HK, Reiter EO, Beitins IZ, Seyed S, Wooten VD, Jimenez, JF, Aiman EJ, DeVane GW, Redman JF, Elders MJ Testicular Leydig cell hyperplaisa as a cause of familial sexual precocity. J Clin Endocrinol Metab 1981; 52:271-278.

2. Rosenthal SM, Grumbach MM, Kaplan SL. Gonadotropinindependent familial sexual precocity with premature Leydig and germinal cell maturation (familial testotoxicosis): Effects of a potent luteinizing hormone-releasing factor agonist and medroxyprogesterone acetate therapy in four cases. J Clin Endocrinol Metab 1983;57:571-579.

3. Laue L, Chan WY, Hsueh AJ, Kudo M, Hsu SY, Wu SM, Blomberg L, Cutler GB Jr. Genetic heterogeneity of constitutively activating mutations of the human luteinizing hormone receptor in familial male-limited precocious puberty. Proc Natl Acad Sci USA 1995;92:1906-1910

4. Shenker A, Laue L, Kosugi S, Merendino JJ Jr, Minegishi T, Cutler GB Jr. A constitutively activating mutation of the luteinizing hormone receptor in familial male precocious puberty. Nature 1993;365:652-654.

5. Gondos B, Egli CA, Rosenthal SM, Grumbach MM. Testicular changes in gonadotropin-independent familial male sexual precocity. Familial testotoxicosis. Arch Pathol Lab Medi 1985;990-995.

6. Leschek EW, Chan WY, Diamond DA, Kaefer M, Jones J, Barnes KM, Cutler GB Jr. Nodular Leydig cell hyperplasia in a boy with familial male-limited precocious puberty. J Pediatr 2001;138:949-951.

7. Bertelloni S, Baroncelli GI, Lala R, Cappa M, Matarazzo P, De Sanctis C, Saggese G. Long-term outcome of male-limited gonadotropin-independent precocious puberty. Horm Res 1997:48:235-239.

8. Latronico AC, Shinozaki H, Guerra G Jr, Pereira MA, Lemos Marini SH, Baptista MT, Arnhold IJ, Fanelli F, Mendonca BB, Segaloff DL. Gonadotropin-independent precocious puberty due to luteinizing hormone receptor mutations in Brazilian boys: a novel constitutively activating mutation in the first transmembrane helix. J Clin Endocrinol Metab 2000;85:4799-4805.

9. Teles M, Brito VN, Arnhold IJ, Mendonca BB, Latronico AC. Preclinical diagnosis of testotoxicosis in a boy with an activating mutation of the luteinizing hormone receptor. J Pediatr Endocrinol Metab 2006;19:541-544.

10. Nagasaki K, Katsumata N, Ogawa Y, Kikuchi T, Uchiyama M. Novel C617Y mutation in the 7th transmembrane segment of luteinizing hormone/choriogonadotropin receptor in a Japanese boy with peripheral precocious puberty. Endocr J 2010;57:1055-1060

11. Gromoll J, Partsch, CJ, Simoni, M., Nordhoff, V, Sippell WG, Nieschlag E, Saxena B. A mutation in the first transmembrane domain of the lutropin receptor causes male precocious puberty. J Clin Endocr Metab 1998;83: 476-480.

12. Laue L, Wu SM, Kudo M, Hsueh AJ, Cutler GB Jr, Jelly DH, Diamond FB, Chan WY. Heterogeneity of activating mutations of the human luteinizing hormone receptor in male-limited precocious puberty. Biochem Mol Med 1996; 58:192-198. 
13. Rosenthal SM, Grumbach MM, Kaplan SL. Gonadotropinindependent familial sexual precocity with premature Leydig and germinal cell maturation (familial testotoxicosis): effects of a potent luteinizing hormone-releasing factor agonist and medroxyprogesterone acetate therapy in four cases. J Clin Endocrinol Metab 1983;57:571-579.

14. Holland FJ, Kirsch SE, Selby R. Gonadotropin-Independent Precocious Puberty ("Testotoxicosis"): Influence of maturational Status on response to ketoconazole. J Clin Endocrinol Metab 1987;64:328-333.

15. Soriano-Guillén L, Lahlou N, Chauvet G, Roger M, Chaussain $\mathrm{J} \mathrm{L}$, Carel JC. Adult height after ketoconazole treatment in patients with familial male-limited precocious puberty. J Clin Endocrinol Metab 2005;90:147-151. Epub 2004 Nov 2

16. Babovic-Vuksanovic D, Donaldson MD, Gibson NA, Wallace AM. Hazards of ketoconazole therapy in testotoxicosis. Acta Paediatr 1994;83:994-997.

17. Almeida MQ, Brito VN, Lins TS, Guerra-Junior G, de Castro $M$, Antonini SR, Arnhold IJ, Mendonca BB, Latronico AC. Longterm treatment of familial male-limited precocious puberty (testotoxicosis) with cyproterone acetate or ketoconazole. Clin Endocrinol (Oxf) 2008;69:93-98. Epub 2008 Jul 1

18. Itoh K, Nakada T, Kubota Y, Suzuki H, Ishigooka M, Izumi T.Testotoxicosis proved by immunohistochemical analysis and successfully treated with cyproterone acetate. Urol Int 1996;57:199-202.

19. Eyssette-Guerreau S, Pinto G, Sultan A, Le Merrer M, Sultan C, Polak M. Effectiveness of anastrozole and cyproterone acetate in two brothers with familial male precocious puberty. J Pediatr Endocrinol Metab 2008;21:995-1002.

20. Mitre N, Lteif A. Treatment of familial male-limited precocious puberty (testotoxicosis) with anastrozole and bicalutamide in a boy with a novel mutation in the luteinizing hormone receptor. J Pediatr Endocrinol Metab 2009;22:1163-1167.

21. Lenz AM, Shulman D, Eugster EA, Rahhal S, Fuqua JS, Pescovitz OH, Lewis KA. Bicalutamide and third- generation aromatase inhibitors in testotoxicosis. Pediatrics 2010;126:728-733. Epub 2010 Aug 16

22. Reiter EO, Mauras N, McCormick K, Kulshreshtha B, Amrhein J, De Luca F, O'Brien S, Armstrong J, Melezinkova $\mathrm{H}$. Bicalutamide plus anastrozole for the treatment of gonadotropin-independent precocious puberty in boys with testotoxicosis: a phase II, open-label pilot study (BATT). J Pediatr Endocrinol Metab 2010;23:999-1009.

23. Wit J M, Hero $M$, Nunez SB. Aromatase inhibitors in Pediatrics. Nat Rev Endocrinol 2011;8:135-147.

24. Martin MM, Wu SM, Martin AL, Rennert O M, Chan WY. Testicular seminoma in a patient with a constitutively activating mutation of the luteinizing hormone/chorionic gonadotropin receptor. Eur J Endocrinol 1998;139:101-106.

25. Ganem JP, Workman KR, Shaban SF. Testicular microlithiasis is associated with testicular pathology. Urology 1999;53:209213.

26. Thomas D, Vlachopapadopoulou E, Papadakis V, Sklavou R, Stefanaki K, Polychronopoulou S, Michalacos S. Testicular microlithiasis in siblings: clinical implications. Pediatric radiol 2008;38:688-690. Epub 2008 Feb 2

27. Dutra RA, Perez-Bóscollo AC, Melo EC, Cruvinel JC. Clinical importance and prevalence of testicular microlithiasis in pediatric patients. Acta Cir Bras 2011;26:387-390.

28. Gougoudi E, Zachariou Z, Kogia E, Zavitsanakis A. Testicular microlithiasis and Leydig cell proliferation in Wistar rats underwent Fowler-Stephens procedure. Pediatr Med Chir 2012;34:192-197.

29. Chien RN, Yang LJ, Lin PY, Liaw YF. Hepatic injury during ketoconazole therapy in patients with onychomycosis: a controlled cohort study. Hepatology 1997;25:103-107.

30. Kim TH, Kim BH, Kim YW, Yang DM, Han YS, Dong $\mathrm{SH}$, Kim HJ, Chang YW, Lee JI, Chang R. Liver cirrhosis developed after ketoconazole-induced acute hepatic injury. J Gastroenterol Hepatol 2003;18:1426-1429. 